\title{
Konaklama İşletmelerinde Atık Yönetimi ve Geri Dönüşüm: İnönü Üniversitesi Kale GöI Otel Örneği
}

\section{Waste Management and Recycling in Hospitality Businesses: A Case of İnönü University Kale Göl Hotel}

\author{
Mustafa Deste, ${ }^{\mathrm{a},{ }^{*}}$ Hulisi Binbaşığlu, ${ }^{\mathrm{b}}$ Mevlüt Türk ${ }^{\mathrm{c}}$ \\ ${ }^{a}$ Dr. Öğr. Üyesi, İnönü Üniversitesi, İktisadi ve İdari Bilimler Fakültesi, İşletme Bölümü, 44280, Malatya/Türkiye. \\ ORCID: 0000-0001-5781-6543

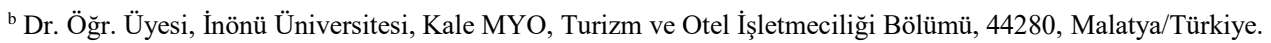 \\ ORCID: 0000-0001-7488-8450
}

c Doç. Dr., İnönü Üniversitesi, İktisadi ve İdari Bilimler Fakültesi, İşletme Bölümü, 44280, Malatya/Türkiye. ORCID: 0000-0003-1316-5800

\section{MAKALE BILGİSİ}

\section{Makale Geçmişi:}

Başvuru tarihi: 30 Nisan 2017

Düzeltme tarihi: 12 Ocak 2018

Kabul tarihi: 28 Şubat 2018

\section{Anahtar Kelimeler:}

Atık Yönetimi

Geri Dönüşüm

Eko-Etiketler

Konaklama İşletmeleri

\section{ARTICLE INFO}

\section{Article history:}

Received 30 April 2017

Received in revised form 12 January 2018

Accepted 28 February 2018

\section{Keywords:}

Waste Management

Recycling

Eco-Labels

Hospitality Businesses

\section{ÖZ}

$\mathrm{Bu}$ çalışmada, konaklama işletmelerinde atık yönetimi ve geri dönüşüm ile ilgili süreçlerin tanımlanmasına ve Yeşil Yıldız kriterleri çerçevesinde bir konaklama işletmesinde bu kriterlerin gerçekleştirilme düzeylerinin ve sorunların belirlenmesine yönelik nitel bir araştırma yapılmıştır. Araştırma sonucunda işletmenin genel yönetim süreçlerinde önemli eksikliklerin olduğu buna karşın projelendirme aşamalarındaki ekolojik mimariye dikkat edilmesinin ve üniversiteye bağlı bir kamu kuruluşu olması dolayısıyla eğitim konusundaki avantajların işletmenin kriterleri karşılama düzeyini artırdığı tespit edilmiştir. İşletmenin kriterleri karşılama düzeyini üst seviyelere çıkarması önemli yatırımları da beraberinde getirecek olsa da orta ve uzun vadede hem maliyet hem de müşteri memnuniyeti açısından önemli katkılar sağlayacağı değerlendirilmiştir. Bununla beraber kısa vadede sadece yönetim anlayışında yapılacak değişiklikler ve çevreci bir bakış açısının benimsenmesiyle kriterlerin karşılanma düzeyinde önemli bir artış sağlanabileceği belirlenmiştir.

\section{A B S T R A C T}

In this study, qualitative research method was carried out to identify the processes of waste management and recycling in hospitality businesses and to determine the level of implementation of these criteria and the problems in a lodging operation within the frame of the Green Star criteria. As a result of this research, it has been found that the operator has significant deficiencies in the general management processes, but the attention of the ecological architects at the projecting stages and the advantages of the education have increased the level of meeting the criteria. Although it would bring significant investments to bring the level of meeting the criteria to the highest level with the operator, it is considered that it would provide important contributions both in terms of cost and customer satisfaction in medium and long term. Nevertheless, it has been determined that only a moderate increase in the level of meeting the criteria can be achieved with the adoption of changes in the management approach and an environmentalist perspective in the short term.

\section{Giriş}

Sürdürülebilirlik, dünyanın biyolojik dengesinin hızlı bir şekilde bozulduğu ve doğal kaynakların azaldığı günümüzde önemi giderek artan bir kavram olarak karşımıza çıkmaktadır. Bu kavram, sadece insanların ihtiyaçtan fazla tüketmesine bağlanamayacak kadar geniş bir kapsama sahiptir. Sürdürülebilirlik, ülkelerin izledikleri ekonomik ve siyasi politikalar, teknolojik gelişmeler, endüstrinin kaynakları kullanma biçimleri başta olmak üzere birçok boyutu olan bir kavram olarak değerlendirilmelidir.

Hizmet veya imalat işletmelerinin sürdürülebilirlik içerisindeki yeri veya başka bir ifade ile işletmeler için bu kavramın ne anlam ifade ettiği sorusu üzerinde son dönemde teorik ve pratik birçok çalışma yapıldığı görülmektedir.

\footnotetext{
* Sorumlu yazar/Corresponding author.

e-posta: mustafa.deste@inonu.edu.tr
} 
(Borges vd., 2014; Varsei, 2016; Roy vd., 2017; Bolis vd., 2017). Bu kapsamda öne çıkan en önemli başlık ise çevre yönetimi kavramıdır. İşletmeler için çevre yönetimi stratejileri, sadece sürdürülebilir olmak adına değil maliyet, rekabet ve müşteri memnuniyeti açısından da önemli avantajlar sağlaması dolayısı ile oluşturulmaktadır.

Çevre yönetimi stratejileri bütün işletmelerde olduğu gibi konaklama işletmelerinde de son derece hayati bir fonksiyona sahiptir. Sürdürülebilirlik çerçevesinde ortaya konan çevre yönetimi uygulamaları, konaklama işletmeleri için önemli bir rekabet aracı haline gelmiştir. Öyle ki işletmeler, bu alandaki faaliyetlerini sadece yasal düzenlemelere uyma ile kalmayıp ulusal veya uluslararası kuruluşlar tarafından belgelendirilerek öz denetim yapmaya da ihtiyaç duymuşlardır (Buckley, 2012).

Dünyada ve Türkiye'de çevreye duyarlı konaklama işletmelerine bu kapsamda verilen birçok sertifika ve belge vardır. Bunlara genel olarak eko-etiket (eco-label) denmektedir. Eko-etiketler, sektörün ve turistlerin çevreye karşı farkındalığının artmasını sağlayan ve özellikle çevresel etkinliğe odaklanan daha çok resmileştirilmiş bir yöntemdir (Font, 2002: 198). Middleton ve Hawkins'e (1998: 240) göre eko-etiket, "bir şirket, ürün veya hizmetin çevresel kimliklerini müşterilerine yönelik olarak ortaya koymak için geliştirilmiş olan bir marka veya logo"dur.

Gerek eko-etiketler gerekse genel çevre yönetimi stratejileri içerisinde atık yönetimi ve geri dönüşüm faaliyetleri en önemli iki başlık olarak yer almaktadır.

\section{Konaklama İşletmelerinde Atık Yönetimi ve Geri Dönüşüm}

Konaklama işletmelerinde, müşterilerin geçici olarak barınma, yeme içme ve diğer kişisel gereksinimlerini karşılayabilmek için çeşitli tedarik ve iç hizmet süreçleri söz konusu olabilmektedir. Bu gereksinimlerin karşılanması ve iç hizmetlerin sağlanması esnasında ortaya çıkan atıklar, bu atıkların uygun bir şekilde toplanması ve değerlendirilmesi konaklama işletmelerinde atık yönetimi ve geri dönüşümü faaliyetleri olarak ifade edilebilir.

Şekil 1: Konaklama İşletmelerinde İç Hizmet Zinciri

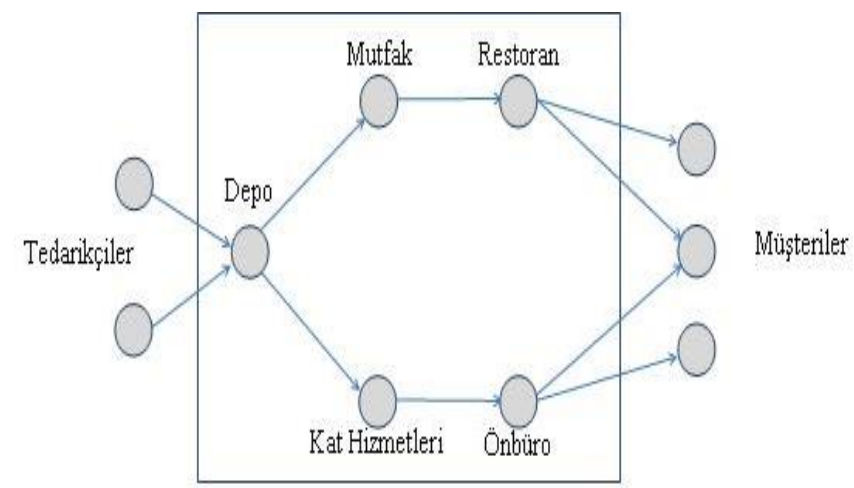

Kaynak: Paraskevas (2001: 253)

İşletmelerin atık yönetimi ve geri dönüşüm faaliyetlerini gerçekleştirirken, motivasyonları maliyet temelli olabileceği gibi çevreye duyarlı bir işletme imajının yaratacağı müşteri memnuniyeti temelli de olabilmektedir.

Maliyet ve memnuniyet kapsamında, konaklama işletmelerindeki atık yönetimi ve geri dönüşüm faaliyetlerini
3T olarak adlandırılan 3 ana başlık altında toplamak mümkündür (Erdal vd., 2010: 468):

(i) Tüketimin azaltılması

(ii) Tekrar kullanım

(iii) Tekrar kazanım (geri dönüşüm)

Tüketimin azaltılması maliyet ve memnuniyet arasında oluşturulacak hassas bir denge ile mümkün olabilecektir. Tüketimin azaltılması için yapılacak çalışmalar müşterilerin ihtiyaçlarının karşılanmasında bir eksikliğe veya müşterilerde yanlış bir algıya sebebiyet vermemelidir.

Tekrar kullanım ve tekrar kazanım çalışmalarında ise tüketimin azaltılmasında olduğu gibi müşteri memnuniyeti ile maliyet arasında ters bir orantı bulunmamaktadır. Müşterilere verilecek olan hizmet sonrasında ortaya çıkacak olan atıkların uygun bir şekilde değerlendirilmesi hem maddi bir kazanca hem de müşterilerde oluşacak çevreye duyarlı bir işletme algısıyla memnuniyete dönüştürebilecektir.

$\mathrm{Bu}$ üç ana başl1k çerçevesinde, bütün işletmelerde olduğu gibi konaklama işletmelerinde de etkin bir atık yönetimi için ilk olarak, ortaya çıkabilecek atık türlerinin neler olduğunu tespit ve tasnif edilmelidir. Konaklama işletmelerinde ortaya çıkabilecek olan atık türleri Tablo 1'de gösterilmiştir.

Ortaya çıkabilecek atık türlerinin belirlenmesinin ardından her bir kalem için uygun bir satın almacı bulunmalıdır. $\mathrm{Bu}$ çerçevede yapılacak anlaşmalar sayesinde, işletme açısından uygulaması zor olan toplama ve ayrıştırma aşamalarının atıkları alacak işletmeler tarafından gerçekleştirilmesi sağlanabilir.

Gerek maliyet gerekse sürdürülebilirlik açısından etkin bir atık yönetimi uygulayan işletmelerin sayısı giderek artmaktadir.

İber Otel Sarıgerme Park, atık yönetimi ve geri dönüşüm politikası uygulanan işletmelere güzel bir örnek olarak verilebilir. Özgen (2005), yapmış olduğu çalışmada Ege bölgesindeki büyük ölçekli kıyı otellerine yönelik atık yönetimi konusunda nicel bir araştırma gerçekleştirmiştir. Bununla birlikte aynı çalışmada, İber Otel Sarıgerme Park örneği üzerinde bir uygulama yapılarak işletmenin atık yönetimi konusundaki politikaları değerlendirilmiş ve sorunlar tespit edilmiştir. Alman tur operatörü TUI Travel'in 2011 yılının en çevreci otellerini belirlediği ve 140 otelin seçildiği listede İber Otel Sarıgerme Park birinci sırada yer almıştır (Getob, 2017).

Aykan vd. (2013), Kayseri ve Nevşehir'de faaliyet göstermekte olan oteller üzerine bir araştırma gerçekleştirmişlerdir. Araştırma sonunda, zincir otellerde reaktif çevresel uygulamaların daha yoğun kullandığı ve algılanan kurumsal itibar üzerinde orta düzeyde bir etkisi olduğu sonucuna ulaşılmıştır.

Atay vd. (2013), uluslararası otel zinciri olan Ibis otellerinin yeşil pazarlama uygulamalarını ve web siteleri içeriklerini incelemiş ve yeşil pazarlama kapsamındaki çalışmaların Ibis otelin zaten var olan kurumsal imajına güç kattığı ve tüketicilerin algısındaki tercih edilebilirliği daha da artırdığı değerlendirmesini yapmışlardır. 
Tablo 1: Konaklama İşletmelerinde Çıkabilecek Atıklar

\begin{tabular}{|c|c|c|c|c|}
\hline \multicolumn{5}{|c|}{ Önbüro (İdari Atıklar) } \\
\hline Gazete & Kartuş & Yazıcı şeridi & Zarf & Etiket \\
\hline Dergi & $\begin{array}{l}\text { Müşteri kayıt } \\
\text { kartı }\end{array}$ & Rezervasyon formu & Bilgisayar çıktısı & Karton mukavva \\
\hline A4 Kağıd1 & Zımba teli & Kalem & Poşet dosya & Post-it \\
\hline Faks kâğ $1 d_{1}$ & Ataç & Not kâğıtları & & \\
\hline \multicolumn{5}{|c|}{ Kat Hizmetleri } \\
\hline Halılar & Bone & Pamuk & Pil & Mum \\
\hline Sprey kutusu & Kağıt havlu & Makyaj pamuğu & Çamaşır torbası & Duvar kâğıtları \\
\hline $\begin{array}{l}\text { Odalarda konulan duş bonesi, } \\
\text { kutu ya da poşet içindeki } \\
\text { sabunlar, plastik şişe içindeki } \\
\text { şampuan ve saç kremi }\end{array}$ & $\begin{array}{l}\text { Kulak } \\
\text { temizleme } \\
\text { çubuğu }\end{array}$ & $\begin{array}{l}\text { Tekstil (perde, pike, çarşaf, } \\
\text { battaniye, alez, yastık kılıfi, } \\
\text { personel üniforması, temizlik } \\
\text { bezleri vb.) }\end{array}$ & $\begin{array}{l}\text { Oda içinde çöp } \\
\text { tenekelerine konulan } \\
\text { poşet torbalar }\end{array}$ & $\begin{array}{l}\text { Deodorant kutuları } \\
\text { ve Kimyasal } \\
\text { ürünlerin kutuları }\end{array}$ \\
\hline \multicolumn{5}{|c|}{ Mutfak / Restoran } \\
\hline Pipet & Yağlar & Streç film & Kavanoz & İçki şişeleri \\
\hline Yiyecek ambalajları & $\begin{array}{l}\text { Kürdan } \\
\text { kağıtları ya da } \\
\text { poşetleri }\end{array}$ & $\begin{array}{l}\text { Sebze ve meyve gibi } \\
\text { malzemelerin hazırlanması } \\
\text { Sırasında çıkan atıklar }\end{array}$ & $\begin{array}{c}\text { Plastik bardak, kaşık, } \\
\text { çatal }\end{array}$ & $\begin{array}{l}\text { Alüminyum teneke } \\
\text { kutular }\end{array}$ \\
\hline Şişe kapakları & Şeker kağıtları & Kahve filtreleri & Buzdolabı poşeti & Alüminyum folyo \\
\hline Strafor bardak & Menüler & Çay poşetleri & Kürdan & Peçete \\
\hline \multicolumn{5}{|c|}{ Genel } \\
\hline Demir & Akü & Boya tenekeleri & Alçı & Floresan, ampul \\
\hline
\end{tabular}

Kaynak: Özgen (2005: 260)

\section{3. Çevreye Duyarlı Konaklama İşletmelerine Verilen Eko-Etiketler}

Günümüzde birçok konaklama işletmesi, faaliyetlerini çevreye duyarlı bir şekilde yürütmektedirler. Çünkü turizm sektörü ve bu kapsamda yürütülen faaliyetlerin hemen hepsi çevreyle ilişkilidir. Konaklama işletmelerinin çevreye duyarlı yürüttüğü faaliyetler, birçok kurum ve kuruluş tarafindan desteklenmekte ve ödüllendirilmektedir. Ekoetiket olarak tanımlanan bu ödüller, çevreye duyarlı faaliyetleri neticesinde işletmelere verilmektedir. Ekoetiketler, turizm sektöründe 1990'ların ortalarında kullanılmaya başlamıştır (Graci vd., 2015).

Dünyada bu etiketlere örnek olarak; "Green Key", "Travelife", "Green Globe" ve "EU Ecolabel" verilebilir. Türkiye'de de konaklama işletmelerine aktif olarak verilen eko-etiketler bulunmaktadır. Bunlar; Kültür ve Turizm Bakanlığı tarafından verilen "Yeşil Yıldız" ile Turistik Otelciler, İşletmeler ve Yatırımcılar Birliği (TUROB) tarafindan verilen "Yeşillenen Oteller (Greening Hotels)" olarak siralanmaktadır.

$\mathrm{Bu}$ etiketlerin sahip olduğu içerik ve kriterlere aşağıda ayrı başlıklar halinde yer verildikten sonra eko-etiketlerin genel bir karşılaştırması ve konuyla ilgili literatür değerlendirilmesi yapılmıştır.

\subsection{Yeşil Yildız}

"Yeşil Yıldız”, Kültür ve Turizm Bakanlığı'nın başlattığı "Çevreye Duyarlı Konaklama Tesisleri” projesi kapsamında Bakanlık belgeli konaklama tesislerine, belirlenen kriterlere uymaları koşuluyla verilen mevcut Turizm İşletmesi Belgelerindeki yıldızların yeşil olarak gösterildiği ve plaketlerinin üzerinde çevreye duyarlı tesis ibaresinin yazıldığı bir çevre etiketi (eko-etiket) uygulamasıdır. Türkiye'de Yeşil Yıldız'a sahip 386 konaklama işletmesi bulunmaktadır. Yeşil Yıldız eko-etiketi kapsamındaki sınıflandırmanın ana başlıkları ve bu başlık konularının puanları aşağıdaki belirtilmektedir (Yatırım ve İşletmeler Genel Müdürlüğü, 2017): (i) Genel yönetim (13 konu üzerinden 72 puan),

(ii) Eğitim (6 konu üzerinden 17 puan),

(iii) Tesisin yatak odalarındaki düzenlemeler (23 konu üzerinden 70 puan),

(iv) Tesisin çevreye uyumu, çevreyi güzelleştirici düzenleme ve etkinlikler ( 6 konu üzerinden 27 puan),

(v) Ekolojik mimari (8 konu üzerinden 42 puan),

(vi) Enerji (22 konu üzerinden 178 puan),

(vii) $\mathrm{Su}$ (16 konu üzerinden 57 puan),

(viii) Deterjanlar, dezenfektanlar ve tehlikeli kimyasal maddeler (6 konu üzerinden 16 puan),

(ix) Atıklar (12 konu üzerinden 53 puan),

(x) Diğer hizmetler (10 konu üzerinden 52 puan).

\subsection{Yeşillenen Oteller (Greening Hotels)}

Turistik Otelciler, İşletmeler ve Yatırımcılar Birliği (TUROB) tarafından 2009 yılında hayata geçirilen ve TUROB, Bureau Veritas ve Sürdürülebilirlik Akademisi iş birliği ile devam eden Yeşillenen Oteller (Greening Hotels) sertifikasyon projesi; sürdürülebilir turizm için turizm tesislerini daha yeşil olmaya teşvik etmektedir. Bu sertifikaya Türkiye'de 53 otel sahiptir (Turob, 2017).

Kriterleri:

(i) Enerji Yönetimi,

(ii) Su Yönetimi,

(iii) İç Hava Kalitesinin Arttırılması,

(iv) Atık Azaltımı / Geri Dönüşüm,

(v) Kurumsal,

(vi) Misafirler.

\subsection{Green Key}

"Green Key”, 54 ülkede 2500'den fazla otelin sahip olduğu, The Foundation for Environmental Education-FEE (Çevresel Eğitim Vakfı) tarafından yürütülen dünya çapında bir eko-etiket türüdür. Bu eko-etikete Türkiye'de ise 86 otel sahiptir (Greenkey, 2017).

Kriterleri:

(i) Çevresel yönetim, 
(ii) Çalıșanların katılımı,

(iii) Konukları bilgilendirme,

(iv) $\mathrm{Su}$,

(v) Y1kama ve temizlik,

(vi) Atıklar,

(vii) Enerji,

(viii) Yiyecek ve içecek,

(ix) Bina içinin çevresi,

(x) Yeşil alanlar,

(xi) Kurumsal sosyal sorumluluk,

(xii) Yeşil aktiviteler,

(xiii) Yönetim.

\subsection{Travelife}

Travelife dünya çapında 1300'den fazla otelin sahip olduğu uluslararası sürdürülebilir bir sertifikasyon programıdır. $\mathrm{Bu}$ etikete Türkiye'de 115 otel sahiptir (Travelife, 2017).

Kriterleri:

(i) Sürdürülebilir yönetim sistemleri,

(ii) Enerji,

(iii) $\mathrm{Su}$,

(iv) Katı atık,

(v) Tehlikeli atıklar,

(vi) Vahşi yaşam,

(vii) İşüüü ve insan hakları,

(viii) Toplumsal entegrasyon,

(ix) Tedarikçiler,

(x) Müşteriler.

\subsection{Green Globe}

Green Globe, turizm işletmelerinin sürdürülebilir performanslarının değerlendirilmesi için yapılandırılmış bir sertifikadır. Bu eko-etikette, 380 uyumluluk göstergesinden oluşan 44 ana kriter mevcuttur. Dünya çapında doksan ülkede 500'ün üzerinde otelde bu sertifika kullanılmaktadır. Bu sertifikaya Türkiye'de ise 7 otel sahiptir (Greenglobe, 2017).

Kriterleri:

(i) Sürdürülebilir yönetim (Sürdürülebilir bir yönetim sistemi, çalışanların eğitimi, müşteri tatmini, sürdürülebilir bina tasarımı ve yapımı, iletişim stratejileri, sağlık ve güvenlik gibi konuları kapsamaktadır.)

(ii) Sosyo-ekonomik (Toplumsal gelişme, yerel işgücü, yerel girişimcilere destek, yerel halka sayg1, çalışanların haklarının korunması gibi konuları kapsamaktadir.)

(iii) Kültürel miras (Davranış kuralları, tarihi eserler, tarihi mekanların korunması, kültürel entegrasyon gibi konuları kapsamaktadır.)

(iv) Çevresel (Çevre dostu ürünlerin satın alınması, enerji ve su tüketimi, enerji ve su yönetimi, tekrar kullanım, geri dönüşüm, doğal yaşamı koruma gibi konuları kapsamaktadır.)

\subsection{EU Ecolabel}

EU Ecolabel Avrupa çapında mal ve hizmetlerin ödüllendirildiği bir çevresel performans sertifikası olan eko etikettir. Avrupa'da 454 otelde bu etiket bulunmaktadır (European Commission, 2017).

Kriterleri: (i) Genel gereksinimler,

(ii) Enerji,

(iii) $\mathrm{Su}$,

(iv) Deterjanlar ve dezenfektanlar,

(v) Attk,

(vi) Diğer hizmetler,

(vii) Genel yönetim.

\subsection{Eko-Etiketlerin Karşılaştırılması ve Literatür Değerlendirmesi}

Yukarıda bahsi geçen eko-etiketlerin kriterlerine göre genel olarak kategorize edilmiş olup aralarındaki farklılıklar aşağıdaki tabloda gösterilmiştir.

Tablo 2. Kriterlere Göre Eko-Etiketler

\begin{tabular}{|c|c|c|c|c|c|c|}
\hline Temel Kriterler & 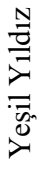 & 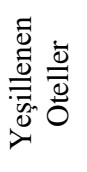 & 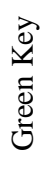 & 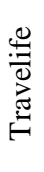 & 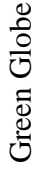 & 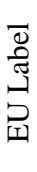 \\
\hline Çevresel Yönetim Anlayışı & $\sqrt{ }$ & $\sqrt{ }$ & $\sqrt{ }$ & $\sqrt{ }$ & $\sqrt{ }$ & $\sqrt{ }$ \\
\hline Çalışanların Katılımı/Eğitimi & $\sqrt{ }$ & $\sqrt{ }$ & $\sqrt{ }$ & $\sqrt{ }$ & $\sqrt{ }$ & $\sqrt{ }$ \\
\hline Enerji & $\sqrt{ }$ & $\sqrt{ }$ & $\sqrt{ }$ & $\sqrt{ }$ & $\sqrt{ }$ & $\sqrt{ }$ \\
\hline $\mathrm{Su}$ & $\sqrt{ }$ & $\sqrt{ }$ & $\sqrt{ }$ & $\sqrt{ }$ & $\sqrt{ }$ & $\sqrt{ }$ \\
\hline Atıklar & $\sqrt{ }$ & $\sqrt{ }$ & $\sqrt{ }$ & $\sqrt{ }$ & $\sqrt{ }$ & $\sqrt{ }$ \\
\hline Temizlik/Temizlik Maddeleri & $\sqrt{ }$ & $\sqrt{ }$ & $\sqrt{ }$ & $\sqrt{ }$ & $\sqrt{ }$ & $\sqrt{ }$ \\
\hline Yiyecek ve İçecek & $\sqrt{ }$ & - & $\sqrt{ }$ & - & $\sqrt{ }$ & - \\
\hline Tesisin Çevreye Uyumu & $\sqrt{ }$ & - & $\sqrt{ }$ & $\sqrt{ }$ & $\sqrt{ }$ & - \\
\hline Sosyal Sorumluluk & $\sqrt{ }$ & - & $\sqrt{ }$ & $\sqrt{ }$ & $\sqrt{ }$ & - \\
\hline Müşteriler & $\sqrt{ }$ & $\sqrt{ }$ & $\sqrt{ }$ & $\sqrt{ }$ & $\sqrt{ }$ & $\sqrt{ }$ \\
\hline Tedarikçiler & $\sqrt{ }$ & - & $\sqrt{ }$ & $\sqrt{ }$ & - & - \\
\hline
\end{tabular}

Tablo 2'de görüldüğü gibi eko-etiketler birbirinden farklı uygulamalar olmalarına rağmen, bunların benzer birçok özelliği bulunmaktadır. Özellikle yönetim, su, enerji ve atık başlıca önemli kriterler arasında gösterilebilir. Ekoetiketlerle ilgili internet siteleri incelendiğinde, bu sitelerde konaklama işletmelerine bu belgeleri nasıl duyuracakları ve müşterilerle iletişime geçerek veya anket uygulayarak bu konuda nasıl farkındalık oluşturacakları ile ilgili yöntemlere de yer verilmiştir.

Bu tür belgelere sahip olmak, işletmeler açısından önemli bir itibar kaynağı oluşturmakta ve müşterilere güven verebilmektedir. Böylece yürütülen bu tür faaliyetler, müşteri sadakatini artırabilmektedir. Bunlarla birlikte ekoetiketlerin; işletmelere kendini geliştirme/eğitme, maliyetleri düşürme, çevre konusunda hassas olan müşterilere etkin ve belirgin bir hizmet verme ve yeşil yıkama (green washing) gibi tüketicileri yanıltan faaliyetlerin önüne geçme benzeri avantajları da bulunmaktadır (Graci vd., 2015).

Çevreye duyarlı konaklama işletmelerine verilen ekoetiketler ile ilgili olarak dünyada ve Türkiye'de yapılmış çalışmalar mevcuttur. Birçok çalışmada eko-etiketler genel olarak incelenmiş veya karşılaştırılmıştır. Bu etiketlere sahip olan otel işletmelerine yönelik çok fazla çalışma bulunmamaktadir. Ancak, bu konuya olan ilginin son 
y1llarda arttı̆̆ı görülmektedir. Mesci (2014), Yeşil Yıldız sahibi bir otelin çevreye duyarlı uygulamalarla işletme ekonomisine de kazanç sağladığını ortaya koymuştur. Doğancili vd. (2015) Yeşil Yıldıza sahip otellerin web sayfasında yeşil yıldız uygulamalarının en çok ne şekilde yer aldıklarını ve bunların hangi sekmelerle tanıtım faaliyetine dönüştürüldüğünü analiz etmiştir. Giritlioğlu vd. (2015) tarafından yapılan bir çalışmada, Gaziantep ve Hatay illerinde faaliyet gösteren 3, 4 ve 5 yıldızlı otellerin Yeşil Yıldız uygulama düzeyleri ortaya konmuş ve bu uygulamaların otellerin statü ve hizmet ettikleri şehre göre farklılık gösterip göstermediği araştırılmıştır. Bir başka araştırmada ise, Yeşil Yıldız sahibi otelleri ziyaret eden müşterilerin bu otelleri tekrar ziyaret etme niyetleri incelenmiştir (Özer vd., 2015). Tosun vd. (2015), Yeşil Yıldız belgesine sahip otellerin, olmayan otellere göre rekabet, maliyet ve işletme politikasında nasıl avantaj sağladığını araştırmıştır. Cömert vd. (2016) ise, sürdürülebilir turizm ve yeşil pazarlama kapsamında, çevreye duyarlılık ve sosyal sorumluluk anlayışı doğrultusunda Yeşil Yıldız projesini incelemiştir. Karaman (2015) yaptığ çalışmada, Yeşillenen Oteller kontrol listesini adapte ederek otellerin kurumsal çevre politikaları ve mutfaklarında gerçekleştirilen günlük faaliyetlerin çevreye ne oranda duyarlı olduğunu belirlemeyi amaçlamıştır.

Reino (2011), Green Key başta olmak üzere sürdürülebilir turizm için uygulamaları olan eko-etiket organizasyonları ile ilgili tüketicilerin görüşlerini araştırmıştır. Rheede vd. (2014) ise Hollanda'da Green Key sahibi otellerin bir metrekarede kullanmış olduğu enerji miktarı ile sertifikasyon seviyesi arasındaki ilişkiyi incelemiştir. Travelife eko-etiketi ile ilgili olarak Christian (2017), bu etiket kriterlerini kullanarak daha adil bir uluslararası turizm alanı oluşturmak için tur operatörlerinin çalışan haklarına ve yetkilendirmeye odaklanan yeni bir yönetişim yaklaşımı sağlaması için yapması gereken çalışmaları ortaya koymaktadır. Griffin vd. (2002), Green Globe sertifikasyon sistemini tüm yönleriyle ele alarak değerlendirmiştir. Schott (2006) ise, Wellington/Yeni Zelenda'ya gelen uluslararası ve yerel ziyaretçilerin Green Globe eko-etiketi hakkındaki farkındalıklarını araştırmıştır. Peri vd. (2012), turistik tesisler ile genel olarak binaları karşılaştırarak, bunların EU Ecolabel açısından benimsenmesini araştırmıştır. Dziuba (2016), bir ekonometrik model vasıtasıyla yaptığı çalışmada, EU Ecolabel standartlarına uygun bir tesisin işletme maliyetlerinde düşüş olup olmadığını ortaya koymuştur. Son olarak Duglio vd. (2017) ise, EU Ecolabel'e sahip olan 36 İtalyan konaklama işletmesini incelemiş ve uygulamalardan kaynaklanan motivasyonları, zorlukları, maliyetleri ve avantajları analiz etmiştir.

\section{4. İnönü Üniversitesi Kale Göl Otel Örneği}

\subsection{Araştırmanın Amacı, Kapsamı ve Yöntemi}

Dünya genelinde artan nüfus ve tüketim, kaynakların hızla azalmasına neden olmakla birlikte atık ve geri dönüşüm kavramlarını da işletmeler için hayati öneme sahip bir noktaya getirmektedir. Bu çerçevede konaklama işletmeleri için de atık yönetimi ve geri dönüşüm, gerek maliyetler açısından gerekse pazarlama ve müşteri memnuniyeti açsından son derece önemlidir.
Son y1llarda ulusal veya uluslararası kapsamda faaliyet gösteren birçok konaklama işletmesi atık yönetimi konusunda çalışmalar yürütmektedir (Font, 2002; Han vd., 2011). Eko-etiket belgelendirme uygulamaları ile devlet veya özel kuruluşlar tarafından bu süreçler için standart oluşturma arayışı da bu konudaki önemli gelişmelerdendir. Çevreye duyarlı konaklama tesisi belgeli işletmelerin listesinin (Yatırım ve İşletmeler Genel Müdürlüğü, 2017) özel sektöre ait konaklama işletmelerden oluşması, bu işletmelerin, rekabet dolayısı ile belgelendirme uygulamalarını önemsedikleri ve bu çerçevede faaliyet yürütme konusunda önemli bir motivasyona sahip oldukları şeklinde yorumlanabilir. Bu çerçevede, kamu kurumlarına ait konaklama işletmelerinin de bu listede yer alabilmesi için, çevre duyarlılığı konusunda daha güçlü bir motivasyonla hareket etmeleri gerektiği söylenebilir.

Buradan hareketle, bir kamu kurumuna bağlı olarak faaliyet göstermekte olan bir konaklama işletmesini, eko-etiket belgelendirme uygulamaları kapsamında ele alarak incelemek, bu konuda kat edilen mesafeyi ve duyarlılığı ortaya koyarak, bazı çıkarımlarda bulunmak; elde edilecek verilerin analizi sonucunda ulaşılacak bilgilerle, bu şekilde faaliyet göstermekte olan üniversitelere bağlı konaklama işletmelerine - uygulama otelleri, misafirhaneler, konuk evleri vb. - yönelik genel bir değerlendirme yapılması, araştırmanın temel amacı olarak belirlenmiştir. Araştırmanın modeli olarak, nitel araştırma modellerinden "örnek olay çalışması" benimsenmiştir.

Örnekleme yöntemi olarak da, "kolay ulaşılabilir durum örneklemesi” yöntemi kullanılmıştır. Bu yöntem çoğunlukla, diğer örnekleme yöntemlerinin kullanım olanağının bulunmadığı ve ayrıca örnekleme ulaşımın daha az maliyetli ve daha kolay ulaşılabilir olduğu durumlarda tercih edilmektedir. (Yıldırım vd, 2011: 113). Bu çerçevede, İnönü Üniversitesine bağlı olarak faaliyet yürütmekte olan ve 3 yıldızlı bir otel statüsüne sahip Kale Göl Oteli örnek olarak seçilmiştir. Kale Göl Otel 51 oda ve 102 yatağa sahip, 200 kişilik restoran, sauna ve buhar odası, kapalı - açık havuzu, step - aerobik - fitness salonu ve Türk hamamiyla İnönü Üniversitesi bünyesinde hizmet vermekte olan bir konaklama işletmesidir.

Örnek olay çalışmalarında birden fazla veri toplama yönteminin kullanılması, araştırmanın da güvenirliğini ve geçerliğini önemli ölçüde artırmaktadır (Yıldırım vd., 2011: 285). Bu kapsamda verilerin toplanmasında yapılandırılmış görüşme, katılımlı gözlem ve belge inceleme tekniklerinden yararlanılmıştır.

Nitel araştırmalarda en çok kullanılan veri toplama yöntemi olan görüşme yöntemi (Ateşoğlu, 2011: 409) kapsamında, yönetici (otel müdürü ve muhasebe müdürü) ve çalışanlarla önceden randevu alınarak üç kez birer saatlik yüz yüze görüşme yapılmıştır. Bu görüşmelerde, Kültür ve Turizm Bakanlığı tarafından verilmekte olan yeşil yıldız çevre etiketi uygulaması çerçevesinde hazırlanan listede yer alan genel yönetim, eğitim, tesisin yatak odalarındaki düzenlemeler, tesisin çevreye uyumu, çevreyi güzelleştirici düzenleme ve etkinlikler, ekolojik mimari, enerji, su, deterjanlar, dezenfektanlar ve tehlikeli kimyasal maddeler, atıklar, diğer hizmetler başlıkları altında ortaya konulmuş olan 122 madde esas alınmıştır (Kültür ve Turizm Bakanlığı, 2014). Yapılan görüşmelerde yöneticilere, listede yer alan kriterlerin sağlanıp sağlanmadığının veya ne derece sağlandığının 
belirlenebilmesi için 122 maddenin her birine yönelik doğrudan sorular yöneltilmiștir.

Araştırmada ayrıca katılımlı gözlem yöntemlerinden gözlemci olarak katılım yöntemi uygulanmıştır. Gözlemci olarak katılımda, araştırmacı araştırmaya konusu içerisinde yer alan sorumlu kişilerle iletişim kurmakta ve gözlem yapmaktadır (Ateşoğlu, 2011: 411). Bu kapsamda ziyaretler sonrasında kriterlerin sağlanması ile ilgili birimlerde (Kat hizmetleri, odalar, mutfak, depolar vb.) gözlemler yapılmıştır.

Belge inceleme aşamasında ise Yıldırım vd. (2011) tarafından belirlenen süreç takip edilmiş ve ilk olarak otel yöneticilerinden elde edilen belgelere ulaşılmış, belgelerin özgünlüğü kontrol edilmiş, bunların anlaşılması ve çözümlenmesi gerçekleştirildikten sonra veriler analiz edilmiş ve kullanılmıștır. Bu belgeler, otelin kültür ve turizm bakanlığına gönderilen başvuru dosyaları ve üniversitenin genelinde yürütülen kalite çalışmaları çerçevesinde hazırlanan dokümanlardan oluşmaktadır. Belge incelmesine ilişkin kodlama süreci ise Yeşil Yıldız listesinde yer alan maddelerin belgelerde bir karşılığı varsa "1", yoksa " 0 " değeri verilerek "var veya yok" şeklinde gerçekleştirilmiştir.

Görüşme ve gözlem yöntemlerinden elde edilen verilerle belgelerden elde edilen veriler karşılaştırılarak, araştırmanın daha geçerli ve güvenilir hale getirilmesi sağlanmıştır.

\subsection{Bulgular ve Analiz}

Genel olarak hazırlanan liste içerisinde yer alan bütün maddeler işletmenin yapısı ve türü dolayısıyla karşılık bulamamıştır.

Genel yönetim başlığı altındaki maddeler çerçevesinde yapılan değerlendirmeler şöyledir:

(i) İşletmenin çevre politikası ve eylem planının olması noktasında herhangi bir faaliyet yürütülmemektedir.

(ii) İşletmenin sistematik bir eylem planının olmamasına karşın tesise hizmet veren veya mal tedarik eden firmaların çevre yönetim sertifikasına (EMAS, ISO 14001 vb.) sahip olmaları işletme için bir tercih nedeni olarak değerlendirilmektedir.

(iii) İşletmede, enerji ve su tüketimini hesaplamak ve izlemek için ilave sayaç ve ölçü aleti kullanılmaktadır.

(iv) Çevre koruma organizasyonlarına düzenli olarak katkıda bulunmak veya bu organizasyonlara düzenli olarak katılmak konusunda işletme çaba göstermektedir.

(v) İşletmede, tesisat ve donanımların koruyucu bakım ve onarımları periyodik olarak yetkili servisler ve uzman kişiler tarafından gerçekleştirilmektedir.

(vi) Isıtma kazanının ve brülörün yılda en az bir defa periyodik olarak bakımı yapılmakta olup, kazan bacasından açığa çıkan emisyonun yetkili kuruluşlar tarafından ölçülüp raporlanması sağlanmaktadır.

Eğitim başlığı altındaki maddeler çerçevesinde yapılan değerlendirmeler ise şu şekildedir:

(i) İşletme çalışanlarına düzenli olarak çevre bilincinin arttırılması yönünde eğitim verilmektedir. (ii) İșletmede olası su arızalarına karșı alınması gereken önlemler ve deterjan, dezenfektan vb. kimyasalların kullanımına yönelik eğitimler verilmektedir.

(iii) Mutfak ve teknik bölümlerde kullanılan cihazların tasarruflu ve verimli kullanılması konusunda personel eğitimleri verilmektedir.

(iv) Misafirlere tesise gelişte, resepsiyonda çevreye duyarlılık noktasında gösterilen çabalardan bahsedilmekte olup müşterilerin katılımı ve desteği alınmaya çalışılmaktadır.

(v) Çocuk misafirlere yönelik etkinlikler yapılmaktadır.

(vi) Tesisin yatak odalarındaki düzenlemeler başlığ altındaki maddeler çerçevesinde yapılan değerlendirmelere aşağıda yer verilmiştir.

(vii) Müşterilere kapı ve pencerelerin açılması halinde, soğutma ve havalandırmanın kapatılmasını hatırlatan bilgilendirmeler yapılmaktadır.

(viii) Odalardaki elektrik sisteminin, müşteriler odadan ayrıldığında otomatik olarak kapanması sağlanarak enerji tasarrufu sağlanmaktadır.

(ix) Odalardaki 1sıtma soğutma sistemi hem merkezi kontrolle hem de bağımsız ayar sistemiyle (termostat) kontrol edilebilmektedir.

(x) Odalarda yer alan cihaz ve makineler, yüksek verimli ve az elektrik tüketen teknolojide olmaları dolayısıyla tercih edilmişlerdir.

(xi) Boş odalarda perdeler ve güneşlikler kapalı tutulmaktadir.

(xii) Rezervuarların her kullanımında daha az su harcanmasını sağlayacak ayarlar bulunmaktadır.

(xiii) Tüm banyolarda duş teknesi veya derinliği azaltılmış küvetler kullanılmaktadır.

(xiv) Banyo ve tuvaletlerde suyun tasarruflu kullanılması ve olası bir arızanın bildirilmesi konusunda müşterilerin bilgilendirilmesi yapılmaktadır.

(xv) Odalarda mümkün olduğunca tek kullanımlık ürünler kullanılmamaya çalışılmaktadır.

(xvi) Tuvaletlerde çöp kutularının bulunması ve müşterilerin çöplerini tuvalet yerine çöp kutusuna atması yönünde bilgilendirilmesi sağlanmaktadır.

(xvii) Tesisteki odaların en az \%50 sinin sigara içilmez olması şartı sağlanmaktadır.

(xviii) Yastık kılıfı, çarşaf, nevresim ve havlular misafirlerin isteğiyle değiştirilmektedir.

(xix) Misafirlerin konaklama işletmesine ve turistik yerlere toplu taşım araçlarını kullanarak gidebilmeleri için gerekli yönlendirmeler yapılmaktadır.

Tesisin çevreye uyumu, çevreyi güzelleştirici düzenleme ve etkinlikler başlığ 1 altındaki maddeler çerçevesinde yapılan değerlendirmeler ise şöyledir:

(i) Peyzaj düzenlemesi ve ağaçlandırma çalışmaları yapılmıştır.

(ii) Tesisi oluşturan yapılar, doğayla uyumlu görünmektedir.

(iii) Tesisin, çevrede bulunan tarihi, doğal ve kültürel değerlerinin korunmasına katkı sağlayacak etkinlikler yapılmaktadır. 
Ekolojik mimari başlığı altındaki maddeler çerçevesinde yapılan değerlendirmeler şu şekildedir:

(i) Tesisin mimarisinde çevreye duyarlı olması dikkate alınmıştır.

(ii) Mimari yapının doğal havalandırmaya mümkün olduğunca imkân sağlaması düşünülmüştür.

(iii) Isı yalıtımı, iklim şartlarına uygun ve enerji verimliliği sağlayacak şekilde yapılmıştır.

(iv) Tesisin dış cephesinde 1sı yalıtımı düşünülerek özel çift camlar kullanılmıştır.

(v) Tesisin çevreye en az zarar verecek şekilde yapıldığını gösteren ÇED raporu bulunmaktadır.

Enerji başlığı altındaki maddeler çerçevesinde yapılan değerlendirmeler aşağıda sıralanmıştır:

(i) Binaların giriş kapılarında rüzgârlık veya hava perdesi bulunmaktadır.

(ii) Tesisin genelinde isıtma ve soğutma kontrolü otomatik olarak yapılmaktadir.

(iii) Tesis genelinde kullanılan cihaz ve makineler, yüksek verimli ve az elektrik tüketen teknolojiye sahiptirler.

(iv) $\mathrm{Az}$ enerji tüketen aydınlatma elemanları kullanılmaktadır.

(v) Tesisteki iç ve diş aydınlatma konunun uzmanları tarafindan projelendirilmiş ve gerekli olan minimum aydınlatma ihtiyacına göre konumlandırılmıştır.

(vi) Tesiste harekete ve 1şı̆̆a duyarlı aydınlatma elemanları kullanılmaktadır.

(vii) Bahçe vb. açık alan aydınlatmalarında kullanılan aydınlatma elemanları, 1şı̆̆ın gökyüzüne gitmesini engelleyecek şekilde düzenlenmiştir.

(viii) Tesisin mutfak ve teknik bölümlerinde kullanılan cihazlar yüksek verimle ve az enerji harcayacak şekilde; güneş 1şı̆̆1, 1sı kaynakları gibi etkilerden uzak ve cihazın havalandırması sağlanacak şekilde yerleştirilmiştir.

(ix) Tesisin sıcak su üretiminde eşanjör (yüksek termal verimlilik sağlayan 1sı değiştirici cihaz) kullanılmaktadır.

(x) Merkezi isıtma sistemi vardır.

(xi) Merkezi 1sıtma sisteminin ihtiyaca uygun olarak kullanılabilmesi amaciyla, binanın bölümlere ayrılarak ısıtılabilmesi imkânı bulunmaktadır.

(xii) Saunada zaman kontrol paneli bulunmaktadır.

(xiii) Çamaşırların doğal yollarla kurutulmasına dikkat edilmektedir.

(xiv) Tesis, genel mahallerde servis hazırlığı yapan personelin elektriği tasarruflu kullanmasını sağlayan aydınlatma donanımına sahiptir.

(xv) Havaya fazla miktarda sera gazı veren kömür veya ağır petrol ürünleri gibi kaynaklar enerji olarak kullanılmamaktadır.

(xvi) Tesiste 1sitma sisteminde ve temiz sicak su ihtiyacının karşılanmasında kullanılan enerjinin \%50'sinin yenilenebilir enerji kaynağından (güneş enerjisinden) sağlanması söz konusudur. Bununla beraber temiz enerji kaynağı olarak ta sıvılaștırılmış doğalgaz (LNG) işletmede kullanılmaktadır.

$\mathrm{Su}$ başlığı altındaki maddeler çerçevesinde yapılan değerlendirmeler aşağıda yer almaktadır:

(i) Genel ve personel duş ve tuvaletlerinde bulunan duş başlıkları ve musluklarında, akan suyun tasarrufuna yönelik özel armatürler kullanılmaktadır.

(ii) Genel tuvaletler ve personel tuvaletlerinde rezervuarların her kullanımında daha az su harcanmasını sağlayacak ayarlar bulunmaktadır.

(iii) Genel duş ve tuvaletlerde suyun tasarruflu kullanılması konusunda misafirler ve personel bilgilendirilmektedir.

(iv) Genel tuvaletlerde çöp kutularının bulunması ve müşterilerin çöplerini tuvalet yerine çöp kutularına atması yönünde bilgilendirilmeler yapılmaktadır.

(v) Su kaçaklarının izlenmesine ve giderilmesine özen gösterilmektedir.

(vi) Yeşil alanların, gün 1şı̆̆ı etkili olmadan önce veya gün 1şı̆̆ etkisini kaybettikten sonra sulanması yapilmaktadır.

(vii) İşletme merkezi bir arıtma sistemine bağlı olmamasına karşın kendine ait atık su arıtma sistemine sahiptir.

(viii) İşletme, yerel idarelerin hazırladığı çevreye duyarlı atık su planına uymaktadır.

(ix) $\mathrm{Su}$ tasarruflu çamaşır ve bulaşık makineleri kullanılmaktadır.

(x) Mutfakta ve bahçede kullanılan suların otomatik olarak kapanmasını sağlayan zaman ayarlı sistem bulunmaktadır.

(xi) Bahçe sulamasında, gereksiz su tüketimini engelleyen damlama, fiskiye vb. teknolojiler kullanılmaktadır.

Deterjanlar, dezenfektanlar ve tehlikeli kimyasal maddeler başlığı altındaki maddeler çerçevesinde yapılan değerlendirmeler 3 madde olarak aşağıdadır:

(i) Dezenfektanların hijyen gerekliliği halinde kullanılmalarına ve çevreye duyarlı deterjan ve dezenfektanların kullanılmasına dikkat edilmektedir.

(ii) Uygun mahallerde kimyasal maddeler kullanılmaksızın temizlik yapılmasına özen gösterilmektedir.

(iii) Haşere ile mücadelede insan sağlığına ve çevreye zarar vermeyen ilaçların kullanılmakta ve doğal tedbirler alınmaktadır.

Tablo 3'te otelde değerlendirilen atık türleri gösterilmekte olup Atıklar başlığ ${ }_{1}$ altındaki maddeler çerçevesinde yapılan değerlendirmelere aşağıda yer verilmiştir.

(i) Personel tarafından zararlı atıkların diğerlerinden ayrılması sağlanmaktadır.

(ii) Yerel idareye, atıkların ayrıştırılması hizmeti verilmesi amaciyla talepte bulunulmuştur.

(iii) Genel duş ve tuvaletlerde, ortak alanlarda tek kullanımlık (şampuan, sabun, duş bonesi, bardak, tabak, çatal bıçak takımları vb.) malzemelerin kullanılmamasına dikkat edilmektedir. 
(iv) Tek kullanımlık paketler (tereyağ 1 , reçel, bal, peynir vb.) kahvaltı için kullanılmamaktadır.

(v) Kullanılan yağların toplanması, mevzuata uygun bir şekilde imhası veya değerlendirilmesi yapılmaktadır.

Tablo 3: Kale Göl Otelde Değerlendirilen Atıklar

\begin{tabular}{|c|c|c|c|}
\hline Gazete & Poşet dosya & $\begin{array}{l}\text { Makyaj } \\
\text { pamuğu }\end{array}$ & Faks kâğıdı \\
\hline Dergi & Pipet & Çay poşetleri & Kürdan \\
\hline A4 Kâğ dd $_{1}$ & Şeker kâğıtları & Yağlar & Bone \\
\hline Pil & Streç film & $\begin{array}{c}\text { Bilgisayar } \\
\text { çıtısı }\end{array}$ & $\begin{array}{l}\text { Alüminyum } \\
\text { folyo }\end{array}$ \\
\hline $\begin{array}{l}\text { Plastik bardak, } \\
\text { kaşık, çatal }\end{array}$ & $\begin{array}{l}\text { Kürdan kâğgtları } \\
\text { ya da poşetleri }\end{array}$ & $\begin{array}{c}\text { Kulak } \\
\text { temizleme } \\
\text { çubuğu }\end{array}$ & $\begin{array}{c}\text { Alüminyum } \\
\text { teneke } \\
\text { kutular }\end{array}$ \\
\hline Kâğıt havlu & Peçete & Not kâğıtları & \\
\hline $\begin{array}{c}\text { Sebze ve meyve } \\
\text { gibi } \\
\text { malzemelerin } \\
\text { hazırlanması } \\
\text { sırasında çıan } \\
\text { atıklar }\end{array}$ & $\begin{array}{l}\text { Odalarda konulan } \\
\text { duş bonesi, kutu } \\
\text { ya da poşet } \\
\text { içindeki sabunlar, } \\
\text { plastik şişe } \\
\text { içindeki şampuan } \\
\text { ve saç kremi }\end{array}$ & $\begin{array}{c}\text { Oda içinde } \\
\text { çöp } \\
\text { tenekelerine } \\
\text { konulan poşet } \\
\text { torbalar }\end{array}$ & \\
\hline
\end{tabular}

Diğer hizmetler başlı̆̆ı altındaki maddeler çerçevesinde yapılan değerlendirmeler ise aşağıdaki gibidir:

(i) Tuvalet kâğıtları ve ofis kâğıtları çevreye duyarlı tip kâğıtlardan tercih edilmektedir.

(ii) En az iki yerel yiyecek ürünü kahvaltı ve ögünlerde sunulmaktadır.

(iii) Açık ve kapalı mahallerde gürültü kirliliği konusunda gürültüsüz cihazların kullanımı, insan sağlığına uygun desibellerde ses yayını yapılması ve gürültü kaynağının perdelenmesi şeklinde önlemler alınmaktadır.

\subsection{Bulgulara İliş̧kin Genel Değerlendirme}

Yeşil yıldız çevre etiketi uygulaması içerisinde yer alan maddelerin işletmede karşılık bulma oranına bakıldığında toplamda yaklaşık \% 61'lik bir oran söz konusudur. Genel yönetim başlı̆̆ 1 altındaki maddelerin işletmede karşılık bulma oranı ise $\% 38,5$ 'dir. Eğitim kapsamında gerçekleştirilen veya karşılık bulan faaliyetlerin oranı $\% 83$, tesisin yatak odalarındaki düzenlemeler kapsamında $\% 70$, tesisin çevreye uyumu, çevreyi güzelleştirici düzenleme ve etkinlikler kapsamında \%50, ekolojik mimari kapsamında $\% 75$, enerji kapsamında \%77, su kapsamında \%69, deterjanlar, dezenfektanlar ve tehlikeli kimyasal maddeler kapsamında \%67, atıklar kapsamında \%42 ve diğer hizmetler kapsaminda \%30'dur.

Yeşil yıldız çevre etiketi uygulaması içerisindeki her bir maddenin farklı puanı bulunmaktadır. Konaklama işletmelerinin bu belgeye sahip olabilmeleri için asgari bir puana ulaşmaları gerekmektedir. Konaklama işletmelerinin tatil tesisi veya şehir tesisi olması durumuna ve sahip oldukları yıldız sayısına göre asgari puan seviyesi değişmektedir. Uygulamanın gerçekleştirildiği Kale Göl Otel, 3 yıldızlı bir tatil tesisi olduğundan dolayı belgeyi alabilmesi için ulaşması gereken asgari puan 170'tir.

İşletme, genel yönetim başlığı altındaki maddelerden 21, eğitimden 12 , tesisin yatak odalarındaki düzenlemelerden
46, tesisin çevreye uyumu, çevreyi güzelleștirici düzenleme ve etkinlikler kapsamında 15, ekolojik mimari kapsamında 27, enerji kapsamında 66, su kapsamında 26, deterjanlar, dezenfektanlar ve tehlikeli kimyasal maddeler kapsamında 10, atıklar kapsamında 25 ve diğer hizmetler kapsamında ise 14 puan alabilecek durumda olarak değerlendirilmiștir. Toplam 262 puana ulaşabilen işletme asgari puan olan 170 seviyesinin üzerine çıkabilmektedir.

İşletmenin almış olduğu puanların alt başlıklar içerisindeki oranlarına bakıldığında, genel yönetim başlığından toplam puanın \%30'nu, eğitimde \% 71 'ini, tesisin yatak odalarındaki düzenlemelerde $\% 63$ 'ünü, tesisin çevreye uyumu, çevreyi güzelleştirici düzenleme ve etkinliklerde $\% 55^{\prime}$ 'ini, ekolojik mimaride \%64'ünü, enerjide \%37,5'ini, suda \%49'unu, deterjanlar, dezenfektanlar ve tehlikeli kimyasal maddeler kapsamında \%62,5'ini, atıklarda \%47'sini ve diğer hizmetlerde ise toplam puanın \%27'sini almışlardır.

\section{Sonuç ve Öneriler}

Tüketiciler gün geçtikçe çevreye daha duyarlı hale gelmekte ve bunun sonucunda da çevreci mal veya hizmetleri tüketmeyi tercih etmektedirler. Bu çerçevede, konaklama işletmeleri de faaliyetlerini yürütürken hem olumlu bir imaj kazanmak hem de çevreye duyarlı faaliyetlerle işletme maliyetlerini düşürmek suretiyle müşteriler tarafından tercih edilmeyi istemektedirler.

Uygulamanın gerçekleştirildiği konaklama işletmesinde yapılan incelemeler sonucunda, genel yönetim kapsamında önemli oranda eksiklikler olmasına karşın diğer faktörlerden alınan puanlarla asgari düzeyin üzerinde bir puana ulaşılabildiği görülmektedir. Burada, başta enerji olmak üzere tesisin yatak odalarındaki düzenlemeler kapsamında alınan puanların büyük önemi bulunmaktadır. Enerji kategorisinden alınan puan yüksek olmasına karşın, bu kategoriden alınabilecek toplam puanın \%37,5'i oranında bir puan alınabilmiştir. $\mathrm{Bu}$ durum, enerji alanında yapılacak iyileştirmelerin işletmeye çok önemli katkılar sağlayacağını göstermektedir. $\mathrm{Bu}$ iyileştirmeler; tesisin bütünü dikkate alındığında önemli ölçüde enerji tasarrufu sağlayacak frekans invertörü (fan ve pompa uygulamalarında, motorun düşük frekansta çalışmasını sağlayarak enerji tasarrufuna katkı sağlanması açısından), ısı geri kazanım sistemi veya 1sı pompası gibi yeni teknolojilerin kullanılması, kullanılan toplam elektrik miktarının yenilenebilir enerji kaynağından sağlanması, 1sıtma sisteminde kullanılan enerjinin tamamının yenilenebilir enerji kaynaklarından sağlanması, soğutma sisteminde kullanılan enerjinin yenilenebilir enerji kaynaklarından sağlanması, temiz sıcak su ihtiyacının tamamının yenilenebilir enerji kaynaklarından sağlanması (Elektrik haricinde; Güneş paneli, jeotermal vb.) şeklinde siralanabilir.

İşletmenin yüksek puan aldığı ikinci başlık olan tesisin yatak odalarındaki düzenlemelerde ise alınan puanın bu başlıktan alınabilecek toplam puana oran $1 \% 63$ olup $\% 37$ oranında kullanılamayan bir potansiyel söz konusudur. Eğitim başlığından sonra işletmenin değerlendirdiği en iyi alanlardan biri tesisin yatak odalarındaki düzenlemelerdir.

Eğitim kapsamında \%71 oranında bir puan alınması, işletmenin üniversiteye bağlı bir kamu kuruluşu olmasıyla ilişkilendirilebilir. Sağlık kültür ve spor dairesi başkanlığına bağlı olarak faaliyet gösteren işletmede, yarı zamanlı 
üniversite öğrencilerinin çalıștırılması, İnönü Üniversitesine bağlı Kale Turizm ve Otel İşletmeciliği Meslek Yüksek Okuluna yakınlığı ve yapılan işbirlikleri, eğitim başlığında yüksek bir oranın yakalanmasının nedeni olarak gösterilebilir. Kamu dışında faaliyet gösteren konaklama işletmelerinin, üniversitelerin turizm ve otelcilik bölümlerinin sağladığı imkânlara sahip olmadıklarından, eğitim alanında yapacağı faaliyetlerin daha maliyetli olacağı ve bu konuda kamuya bağlı işletmelere karşı önemli bir dezavantajlarının olduğu söylenebilir.

Ekolojik mimari kapsamında \%64 oranında bir puana ulaşılması, tesisin projelendirilmesi aşamasında yapılan çevreci tasarım sonucunda mümkün olmuştur. Bu durum, çevreci anlayışın işletmelerin inşa edilmeden önce benimsenmesinin önemini ortaya koymaktadır. Böylece, önceden düşünülen çevreci uygulamaların, sonradan uygulanmaya çalışılanlara kıyasla çok daha kolay ve daha düşük maliyetlerle gerçekleştirilebileceği söylenebilir.

Sonuç olarak, işletme asgari 170 puan alınması gereken yeşil yıldız belgelendirme uygulamasında, çok ciddi bir yönetimsel çaba sarf etmeyerek, gerek kamu kuruluşu olmasının getirdiği projelendirme süreçlerindeki avantajı gerekse eğitim kapsamındaki potansiyeli dolayısıyla toplam 262 puanlık bir değere ulaşabilmektedir. Ancak, alınabilecek toplam puanın 579 olduğu dikkate alındığında, işletmenin sadece \%45'lik bir oranı yakalayabildiği görülmektedir. İşletmenin bu oranı daha yukarılara taşıması, hem maliyet hem de müşteri memnuniyeti açısından önemli katkılar sağlayacaktır. Bu oranın en üst seviyeye çıkarılması, önemli yatırımları da beraberinde getirecek olsa da sadece yönetim anlayışında yapılacak değişiklikler ve çevreci bir bakış açısının benimsenmesi ile önemli bir artış sağlanabilecektir. Ateşoğlu vd. (2010), konaklama işletmelerinin sosyal sorumluluk faaliyetlerine yönelik olarak yapmış oldukları çalışmada, konaklama işletmelerinin yerel halkın sorunlarına, toplumsal olaylara, kültürel gelişime yönelik sosyal sorumluluk faaliyetlerine yeterince önem vermedikleri yönünde benzer bulgulara ulaşmışlardır. Dolmacı vd. (2013) tarafindan çevresel duyarlılık üzerine yapılan bir başka çalışmada ise çevrede ve doğada gerçekleşen kirlenmeyi, sadece teknoloji vasıtasıyla yenmenin mümkün olmadığı, bu konuda alınması gereken önlemlerin başında bireylerin çevreye ve doğaya yaklaşımlarının değiştirilmesinin geldiği vurgulanmıştır.

Kale Göl Otelin İnönü Üniversitesine bağlı bir kamu kuruluşu olduğu düşünüldüğünde yapılan değerlendirmelerin diğer üniversitelere bağlı konaklama işletmeleri için de bir fikir verebileceğini söylemek mümkündür. $\mathrm{Bu}$ araştırma sonuçlarının girdi olarak kullanılacağı, benzer kamu kuruluşlarını da içine alan daha kapsamlı bir araştırma gelecek çalışma konusu olarak belirlenmiştir.

\section{Kaynakça}

Atay, L., \& Dilek, S. E. (2013). Konaklama İşletmelerinde Yeşil Pazarlama Uygulamaları: Ibis Otel Örneği. Süleyman Demirel Üniversitesi İktisadi ve İdari Bilimler Fakültesi Dergisi, 18(1), 203-219.

Ateşoğlu, İ. (2011). Nitel Araştırmalar ve Nitel Verilerin Analizi, iç. Pazarlama Araştırması. (Ed. Ayşe Şahin \& Burak Kartal), s. 403-418. İstanbul: Lisans Yayıncılık.
Ateşoğlu, İ., \& Türker, A. (2010). Konaklama İşletmelerinin Sosyal Sorumluluk Faaliyetlerine Yaklaşımı: Muğla İli Örneği. Süleyman Demirel Üniversitesi İktisadi ve İdari Bilimler Fakültesi Dergisi, 15(3), 207-226.

Aykan, E., \& Sevim, B. (2013). Konaklama İşletmelerinde Çevre Yönetimi Uygulamaları ve Algılanan Kurumsal İtibar Üzerindeki Etkisi: Kayseri ve Nevşehir Otelleri Üzerinde Bir Araştırma. İşletme Araştırmaları Dergisi, 5(3), 93-113.

Bolis, I., Morioka, S. N., \& Sznelwar, L. I. (2017). Review: Are We Making Decisions in A Sustainable Way? A Comprehensive Literature Review About Rationalities For Sustainable Development. Journal of Cleaner Production, 145, 310-322.

Borges, M. R., Eusébio, C., \& Carvalho, N. (2014). Governance For Sustainable Tourism: A Review and Directions For Future Research. European Journal of Tourism Research, 7(1), 45-56.

Buckley, R. (2012). Sustainability Reporting and Certification in Tourism. Tourism Recreation Research, 37(1), 85-90.

Christian, M. (2017). Protecting tourism labor? Sustainable labels and private governance. GeoJournal, 82(4), 805821.

Cömert, M., \& Özata, E. (2016). Sürdürülebilir Turizm Kapsamında Yeşil Yıldız Çevreye Duyarlılık Projesi. Uluslararası Sosyal Araştırmalar Dergisi. 47(9), 11691178.

Doğancili, O.S., \& Akbulut, B.A. (2015). Yeşil Yıldız Çevre Etiketine Sahip Otellerin Web Sitelerinde Yeşil Pazarlamayı Kullanmalarına İlişkin İçerik Analizi. 16. Ulusal Turizm Kongresi, Çanakkale 18 Mart Üniversitesi, 12-13 Kasim 2015.

Dolmac1, N., \& Bulgan, G. (2013). Turizm Etiği Kapsamında Çevresel Duyarlılık. Journal of Yasar University, 29(9), 4853-487.

Duglio, S., Ivanov, S., Magliano, F., \& Ivanova, M. (2017). Motivation, Costs and Benefits of the Adoption of the European Ecolabel in the Tourism Sector: An Exploratory Study of Italian Accommodation Establishments. Izvestiya Journal of Varna University of Economics, 61(1), 83-95.

Dziuba, R. (2016). Sustainable Development of Tourism EU Ecolabel Standards Illustrated Using The Example of Poland. Comparative Economic Research, 19(2), 111128.

European Commission (2017). Ecolabel. (Erişim. 30.04.2017), http://ec.europa.eu/environment/ecolabel/

Erdal, M., Görçün, Ö. F., Görçün, Ö., \& Saygıll, M. S., (2010). Entegre Lojistik Yönetimi, Beta Yayınc1lı, İstanbul.

Font, X. (2002). Environmental Certification in Tourism and Hospitality Progress, Process and Prospects. Tourism Management, 23, 197-205. 
Getob (2017). 25 Türk Oteli TUI'nin Çevreci Oteller Listesine Girdi. (Erişim: 30.04.2017), http://www.getob.org/?p=2762

Giritlioğlu, İ., \& Güzel, M.O. (2015). Otel İşletmelerinde Yeşil Yıldız Uygulamaları Gaziantep ve Hatay Bölgesinde Bir Araştırma. Uluslararast Sosyal Araştırmalar Dergisi, 40(8), 889-904.

Graci, S., \& Dodds, R. (2015). Certification and Labeling, iç. The Routledge Handbook of Tourism and Sustainability. (Ed. C. Michael Hall, Stefan Gössling \& Daniel Scott), s. 200-208. London: Routledge.

Greenglobe (2017). Green Globe Certification. (Erişim: 30.04.2017), https://greenglobe.com/

Greenkey (2017). Green Key Global. (Erişim: 30.04.2017), http://www.greenkey.global/

Griffin, T., \& DeLacey, T. (2002). Green Globe: Sustainability Accreditation For Tourism, iç. Sustainable Tourism: A Global Perspective. (Ed. Rob Harris, Tony Griffin \& Peter Williams), s. 58-88. Oxford: Butterworth-Heinemann.

Han, H., Hsu, L. T. J., Lee, J. S., \& Sheu, C. (2011). Are lodging customers ready to go green? An examination of attitudes, demographics, and eco-friendly intentions. International Journal of Hospitality Management, 30(2), 345-355.

Karaman, H. (2015). Otellerin Kurumsal Çevre Politikalarının ve Mutfaklarında Çevreye Duyarlı Uygulamalarının Mutfak Personeli Aracılı̆̆ıla Belirlenmesi (Konya Örneği). Yüksek Lisans Tezi. Konya: Selçuk Üniversitesi.

Kültür ve Turizm Bakanlığı (2014). Yeşil Yıldız Bilgi Broşürü. (Erişim: 30.04.2017), http://tuyup.turizm.gov. tr/Yayinlar/Yeşil\%20Yıldız\%20Bilgi\%20Broşürü.pdf

Mesci, Z. (2014). Otellerin Çevreci Uygulamalarının Değerlendirilmesi: Yeşil Yıldızlı Bir Otel İşletmesinde Örnek Olay Çalışması. Seyahat ve Otel İşletmeciliği Dergisi, 11(1), 90-102.

Middleton, V.T.C., \& Hawkins, R. (1998). Sustainable tourism: A marketing perspective. Oxford: ButterworthHeinamann.

Özer, L., Kement, Ü., \& Gültekin, B. (2015). Genişletilmiş Planlanmış Davranış Teorisi Kapsamında Yeşil Yıldızlı Otelleri Tekrar Ziyaret Etme. Hacettepe Üniversitesi Íktisadi ve İdari Bilimler Fakültesi Dergisi, 33(4), 59-85.

Özgen, I. (2005). Büyük Ölçekli Otel İşletmelerinde Atık Yönetimi ve İber Otel Sarlgerme Park Örneği. Doktora Tezi. İzmir: Dokuz Eylül Üniversitesi.

Paraskevas, A. (2001). Exploring hotel internal service chains: a theoretical approach. International Journal of Contemporary Hospitality Management, 13(5), 251-258.

Peri, G., \& Rizzo, G. (2012). The Overall Classification of Residential Buildings: Possible Role of Tourist EU Ecolabel Award Scheme. Building and Environment, 56, 151-161.
Reino, S. (2011). European Sustainable Tourism Labels: A Tool to Inform and Educate Consumers?. Edinburgh: Queen Margaret University.

Rheede, A.V., \& Rietbergen, M. (2014). Is The Green Key Standard The Golden Key For Sustainability Measurement in The Hospitality Sector?. 20th Annual International Sustainable Development Research Conference, Norwegian University of Science and Technology, Trondheim, Norway, June 18-20, 2014.

Roy, V., \& Singh, S. (2017). Review: Mapping The Business Focus in Sustainable Production and Consumption Literature: Review and Research Framework. Journal of Cleaner Production, 150, 224-236.

Schott, C. (2006). Proactive Crises Management Tools: Ecolabel and Green Globe 21 Experiences From New Zealand. Tourism Review International, 10(1-2), 81-90.

Tosun, C., \& Özdemir, S. (2015). Çevreye Duyarlı Konaklama İşletmelerinde Yöneticiler Açısından Rekabet Avantaj1 Olarak Yeşil Yıldız Uygulaması. Journal of Recreation and Tourism Research, 2(4), 2636.

Travelife (2017). Travelife Sustainability in Tourism. (Erişim: 30.04.2017), http://www.travelife.org

Turob (2017). Türkiye Otelciler Birliği. (Erişim: 30.04.2017), http://www.turob.com/

Varsei, M. (2016). Sustainable Supply Chain Management: A Brief Literature Review. Journal of Developing Areas, 50(6), 411-419.

Yatırım ve İşletmeler Genel Müdürlüğü (2017). Çevreye Duyarlılık Kampanyası: Yeşil Yıldız. (Erişim: 30.04.2017), http://yigm.kulturturizm.gov.tr/TR,11596/ cevreye-duyarlilik-kampanyasi-yesil-yildiz.html

Yıldırım, A., \& Şimşek, H. (2011). Sosyal Bilimlerde Nitel Araştırma Yöntemleri. Ankara: Seçkin Yayıncılık. 